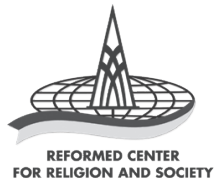

Societas Dei: Jurnal Agama dan Masyarakat Vol. 08, No. 1 (April 2021): 7-30

http://societasdei.rcrs.org/index.php/SD/issue/archive

p-ISSN: 2407-0556; e-ISSN: 2599-3267

DOI: $10.33550 /$ sd.v8i1.191

Received: 26 October 2020

Revised: 7 December 2020

Accepted: 19 January 2021

\title{
TINJAUAN ETIS-TEOLOGIS TERHADAP TRADISI BELIS DI PULAU SUMBA BERDASARKAN KONSEP MAHAR DALAM ALKITAB
}

\section{ETHICAL AND THEOLOGICAL ANALYSIS TO THE BELIS TRADITION IN SUMBA BASED ON BIBLICAL CONCEPT OF DOWRY}

Johanis Putratama Kamuri \& Grace Mariany Toumeluk

Sekolah Tinggi Teologi Reformed Injili Internasional, Jakarta tama.kamuri@gmail.com 


\begin{abstract}
:
This paper is aimed to determine the appropriate Christian attitude towards the practice of belis (dowry) in Sumba Island. The biblical, anthropological, and sociological concepts of dowry are the conceptual framework for understanding and analyzing the concept of belis. Based on systematic reviews and asymmetric comparisons of the Sumbanese belis concepts and biblical concept of dowry, it is found that rejection of the practice of belis is unnecessary. Belis can be practiced by Sumbanese Christians with a critical attitude. The goal is the transformation of the belis culture. Transformation is achieved through several actions: doing belis principles that do not conflict with biblical principles; rejecting the principles that conflict with biblical principles; and avoiding the practices of belis which have been distorted by deviating motivations either from the biblical or the rights belis principles. Keywords: Belis; Dowry; Marapu; Sumba; Cultural Transformation.
\end{abstract}

\begin{abstract}
Abstrak:
Tulisan ini bertujuan menentukan dengan tepat sikap orang Kristen terhadap praktik belis (mahar) di Pulau Sumba. Analisis terhadap konsep belis dilakukan dengan memanfaatkan konsep biblikal, antropologis, dan sosiologis tentang mahar. Berdasarkan systematic reviews dan perbandingan asimetris terhadap konsep orang Sumba tentang belis dan konsep biblikal tentang mahar, ditemukan bahwa praktik belis tidak bertentangan dengan iman Kristen. Tetapi orang Kristen Sumba harus mempraktikkan budaya belis dengan sikap kritis. Tujuannya adalah transformasi budaya belis. Transformasi dicapai melalui beberapa sikap, antara lain: mempertahankan prinsip-prinsip belis yang sesuai dengan Alkitab, menolak prinsip-prinsip yang bertentangan dengan Alkitab, dan menghindari praktik belis yang terdistorsi oleh motivasi yang menyimpang dari Alkitab maupun prinsip belis yang benar.
\end{abstract}

Kata-kata Kunci: belis; mahar; Marapu; Sumba; Transformasi Budaya. 


\section{Pendahuluan}

Penelitian ini mempersoalkan makna belis (mahar) dalam konteks agama Marapu dan bagaimana harusnya orang Kristen bersikap terhadap budaya belis di Sumba. Penulis berusaha menjawab permasalahan tersebut untuk memperoleh pengertian yang tepat mengenai praktik belis dan menemukan sikap yang tepat secara etis-teologis terhadap praktik belis.

Mahar merupakan tradisi yang dapat dijumpai pada berbagai kebudayaan di berbagai belahan dunia, termasuk pada suku-suku bangsa di Indonesia. ${ }^{1}$ Meski bentuknya berbeda, umumnya pembayaran mahar menjadi bagian integral dari sebuah pernikahan. Di Nusa Tenggara Timur (NTT), termasuk di Pulau Sumba, masyarakat menggunakan istilah belis untuk mahar dan "bayar belis" untuk pembayaran mahar.

Di Pulau Sumba tradisi belis melekat erat pada agama Marapu², yaitu pemujaan leluhur yang sudah bereksistensi sebelum Negara Kesatuan Republik Indonesia (NKRI) berdiri. Umumnya, agama yang menjadi bagian integral sebuah suku merupakan penentu budaya dan identitas masyarakat. ${ }^{3}$ Demikian halnya di Sumba, agama Marapu menjadi sumber kebudayaan orang Sumba. Dalam tradisi yang diturunkan Marapu, belis adalah penanda penghormatan terhadap keluarga calon mempelai perempuan, prestise, dan status sosial keluarga kedua mempelai. ${ }^{4}$ Ini berarti belis memiliki tujuan positif.

Namun faktanya tradisi belis menimbulkan sejumlah persoalan, seperti kerugian ekonomi, kemiskinan, dan kerenggangan relasi, bahkan konflik di antara pihak-pihak yang terlibat. ${ }^{5}$ Sebagian orang menganggap motif ekonomi atau negosiasi transaksional dan usaha menegakkan gengsi masing-masing keluarga sebagai penyebabnya. ${ }^{6}$ Belis juga dianggap sebagai budaya yang menjadikan perempuan sebagai "barang belian", sehingga dapat diperlakukan sewenang-wenang. Kekerasan terhadap perempuan

\footnotetext{
Jan Boersema, Perjumpaan Injil dan Budaya dalam Kawin-Mawin (Jakarta: Yayasan Komunikasi Bina Kasih, 2015), 18.

Argumentasi untuk menunjukkan bahwa Marapu adalah agama asli orang Sumba dapat diakses dalam tulisan Johanis Putratama Kamuri, "Menimbang Posisi Penganut Marapu di Hadapan Pemerintah Negara Republik Indonesia," Societas Dei: Jurnal Agama dan Masyarakat 7, no. 1 (2020): 80-83.

3 Tatiana Alybina, "Vernacular Beliefs and Official Traditional Religion: The Position and Meaning of the Mari Worldview in the Current Context," Approaching Religion 4, no. 1 (2014): 89.

4 Dony Kleden, "Belis dan Harga Seorang Perempuan Sumba (Perkawinan Adat Suku Wewewa, Sumba Barat Daya, NTT)," Jurnal Studi Budaya Nusantara 1, no. 1 (2017): 33.

Yonathan Lu Walukati, "Tradisi Kawin Mawin Suku Sumba: Belis atau Beli?," Kompasiana, terakhir dimodifikasi 2018, https://www.kompasiana.com/yonshunga/ 5bcfcf5aaeebe143155b87d5/tradisikawin-mawin-suku-sumba-belis-atau-beli?page=2.

Anggraeni, Silvia, Beding, B. Michael, Kalunga, Norlina R. Jola, Yuwono, Godril D., Perempuan Sumba dan Belis (Sumba Timur: BAPPEDA Pemerintah Kabupaten Sumba Timur dan Lembaga Pro Millenio Center, 2003), 2-3.
} 
dikaitkan dengan situasi ini. ${ }^{7}$ Ada juga yang menunjuk pada keterkaitan belis dengan agama Marapu, yang dianggap kafir, sebagai penyebabnya. Akibatnya, praktik belis dipahami negatif, baik oleh sebagian orang Sumba maupun oleh masyarakat di luar Pulau Sumba.

Hal ini menyebabkan perbedaan pandangan. Di satu sisi, belis dianggap berdampak negatif, bahkan identik dengan cara hidup primitif dan kafir. Oleh sebab itu, muncul kecenderungan menolak budaya belis. Pemerintah Kabupaten Sumba Barat Daya bersikap moderat melalui Perda tahun 2009 yang mengatur pembatasan harga belis. ${ }^{8} \mathrm{Di}$ sisi lain, ada kecenderungan mempertahankan belis sebagai tradisi leluhur dan identitas budaya. Ini membuat sikap moderat, seperti yang diambil Pemerintah Kabupaten Sumba Barat Daya, dianggap gegabah dan mencederai identitas budaya orang Sumba. ${ }^{9}$

Oleh sebab itu, tulisan ini meneliti falsafah Marapu di balik budaya belis untuk memahami apakah tradisi belis bermasalah pada dirinya sehingga dapat menyebabkan berbagai persoalan yang disebutkan sebelumnya. Tulisan ini juga memberi evaluasi dari sudut pandang teologi Kristen terhadap budaya belis. Dengan demikian, orang Kristen di Sumba dapat mempertimbangkan sikap yang seharusnya terhadap belis. Hal ini signifikan karena hingga saat ini orang Sumba beragama Kristen, yang menjadi anggota Gereja Kristen Sumba (GKS), berjumlah lebih dari 426.192 jiwa. ${ }^{10}$ Jumlah ini merupakan jumlah mayoritas penduduk Pulau Sumba dan belum termasuk orang Sumba beragama Kristen yang menjadi anggota denomimasi gereja lainnya. Bukan tidak mungkin sebagian di antara mereka merupakan pelaku praktik belis yang dipersoalkan di atas. Hasil penelitian ini dapat dijadikan pertimbangan oleh orang Kristen Sumba atau pemimpin gereja di Sumba dalam bersikap terhadap belis.

\section{Kajian Literatur}

Permasalahan dan tujuan penelitian menegaskan keunikan tulisan ini jika dibandingkan dengan penelitian-penelitian terdahulu yang berkaitan atau berpotongan dengan objek kajian tulisan ini, yakni: agama dan kebudayaan Marapu, telaah teologis terhadap kebudayaan Marapu, dan penelitian terkait budaya belis. Kamuri menunjukkan bahwa prinsip-prinsip Marapu merupakan kekuatan penentu komitmen religius orang Sumba,

\footnotetext{
Ibid., 3.

Wara, Yanuarius L., Widianto, Tri., Purwiyastuti, Wahyu., Tradisi Belis dalam Upacara Perkawinan dan Perubahan Sosial, Budaya, Ekonomi Masyarakat Sumba Barat Daya (Semarang: Widya Sari Press, 2015), 6.

Kleden, "Belis dan Harga Seorang Perempuan Sumba," 34.

10 Sekretariat Sinode GKS, Garis-Garis Besar Kebijakan Umum Gereja Kristen Sumba (GBKU-GKS) Periode 2014-2018 (Waingapu: Badan Pelaksana Majelis Sinode GKS, 2014), 5.
} 
sehingga sebagian orang Kristen Sumba menghidupi kehidupan Kristen bercorak Marapu. ${ }^{11}$ Penelitian Kamuri menunjukkan kuatnya pengaruh Marapu terhadap cara pikir dan kehidupan orang Sumba, karena Marapu menjadi bingkai interpretasi terhadap realita. Meski memberi perhatian pada prinsip-prinsip agama Marapu, tulisan ini berbeda dari penelitian Kamuri karena tidak berfokus pada peran prinsip-prinsip Marapu sebagai bingkai interpretasi, melainkan pada prinsip-prinsip Marapu yang berkaitan dengan budaya belis.

Tulisan ini juga berbeda dari penelitian terdahulu yang membahas budaya belis. Kleden mendeskripsikan jenis-jenis perkawinan dalam suku Wewewa, memberi catatan kritis terkait belis dalam pekawinan, dan menunjukkan pembelaan terhadapnya. ${ }^{12}$ Anggraeni, Beding, Kalunga, dan Yuwono menggali permasalahan seputar peran belis dan persepsi masyarakat terhadap perempuan Sumba dalam kaitan dengan tradisi belis. ${ }^{13}$ Kedua penelitian tersebut mendeskripsikan budaya belis, kemudian merefleksikannya secara kritis. Tulisan pertama membela budaya belis sedangkan yang kedua mengkritik penyimpangan dan dampak negatifnya. Berbeda dari dua penelitian tersebut, tulisan ini merupakan kajian teologis Kristen terhadap budaya belis untuk menentukan jalan tengah di antara dua sikap ekstrem terhadap budaya tersebut.

Kajian teologis terhadap Marapu dapat ditemukan dalam berbagai penelitian seperti karya Wellem, kajian historis-teologis tentang dinamika dan persoalan teologis dalam perjumpaan antara Injil dan Marapu. ${ }^{14}$ Sementara itu berdasarkan prinsip penciptaan dalam Marapu, Natar membentuk perspektif teologis kontekstual yang dapat mempengaruhi cara pikir dan cara hidup orang Sumba dalam usaha menyelesaikan persoalan ekologis di Sumba. ${ }^{15}$ Penelitian Natar mengindikasikan bahwa kearifan lokal dalam kebudayaan Marapu tidak harus disingkirkan orang Kristen. Sebaliknya ada unsur kebudayaan Marapu (seperti belis) yang dapat dikaji secara teologis dan dimanfaatkan untuk melengkapi kehidupan orang Kristen di Sumba. Berbeda dari karakter penelitian Wellem, tulisan ini bukanlah penelitian teologis dari perspektif historis. Tulisan ini juga berbeda dari Natar, karena tidak bertujuan mengonstruksi konsep teologis tertentu. Tulisan ini

\footnotetext{
11 Johanis Putratama Kamuri, “Transformasi Wawasan Dunia Marapu: Tantangan Pembinaan Warga Gereja di Sumba," Evangelikal: Jurnal Teologi Injili dan Pembinaan Warga Jemaat 4, no. 2 (2020): 131-143.

12 Kleden, "Belis dan Harga Seorang Perempuan Sumba," 24-34.

13 Silvia Anggraeni dkk., Perempuan Sumba dan Belis, 7.

14 F.D. Wellem, Injil dan Marapu: Suatu Studi Historis-Teologis tentang Perjumpaan Injil dengan Masyarakat Sumba pada Periode 1876-1990 (Jakarta: BPK Gunung Mulia, 2004), 1-11.

15 Asnath Niwa Natar, "Penciptaan Dalam Perspektif Sumba: Suatu Upaya Berteologi Ekologi Kontekstual," GEMA TEOLOGIKA: Jurnal Teologi Kontekstual dan Filsafat Keilahian 4, no. 1 (2019): 101-120.
} 
JOHANIS PUTRATAMA KAMURI \& GRACE MARIANY TOUMELUK

bersifat etis-teologis karena memanfaatkan prinsip-prinsip teologi Kristen untuk menemukan jalan tengah dalam ketegangan antara pihak-pihak yang menolak dan menerima pelaksanan tradisi belis.

\section{Metode Penelitian}

Tujuan penelitian dicapai melalui library research yang mengandalkan literatur sebagai sumber data utama. ${ }^{16}$ Penelitian ini memanfaatkan dua kategori literatur utama: literatur yang berkaitan dengan belis dalam konteks agama dan kebudayaan Marapu, serta literatur yang mempertajam pemahaman biblikal terhadap konsep mahar dalam Alkitab.

Literatur didekati dengan systematic reviews, yakni studi yang tidak hanya berfokus pada persoalan praktis dan solusinya dalam kehidupan bermasyarakat tetapi juga menekankan kriteria yang jelas dan pendekatan sistematis dalam melakukan review terhadap literatur. ${ }^{17}$ Penelitian ini akan menempuh beberapa langkah utama. Pertama, melakukan review literatur untuk mengidentifikasi permasalahan penelitian, sebagaimana dipaparkan pada bagian sebelumnya. Kedua, mempraktikkan review terhadap literatur yang memungkinkan penjelasan terbaik terhadap masalah penelitian. Hal ini diawali dengan me-review literatur yang bersumber dari berbagai penelitian antropologis dan sosiologis untuk memahami konsep dan prinsip belis menurut Marapu. Pemahaman ini penting, karena penilaian yang lebih objektif hanya dapat dilakukan jika prinsip-prinsip tersebut terpahami dengan baik. Selanjutnya adalah melakukan review terhadap literatur yang memberi pemahaman terhadap konsep mahar dalam Alkitab.

Karena penelitian ini bertujuan menentukan posisi Kristen terhadap permasalahan belis di Sumba, maka langkah ketiga adalah melakukan analisis terhadap konsep belis dalam agama dan kebudayaan Marapu berdasarkan konsep Alkitab tentang mahar. Jadi, konsep Alkitab digunakan sebagai kriteria atau pisau analisis utama dengan didukung oleh sejumlah ide yang tidak bertentangan dengan Alkitab dan bersumber dari berbagai penelitian sosiologis dan antropologis terhadap belis. Analisis dilakukan dengan komparasi asimetris di mana konsep belis dipaparkan terlebih dahulu dan sesudah itu konsep Alkitab tentang mahar dipaparkan sekaligus diperbandingkan dengan konsep belis. Oleh sebab itu, uraian diawali dengan penjelasan tentang masalah penelitian dan metode yang digunakan untuk menjawab permasalahan. Selanjutnya adalah mengurai agama Marapu dan konsep belis di Pulau Sumba, diikuti dengan penjelasan

\footnotetext{
16 Martyn Denscombe, The Good Research Guide: For Small-Scale Social Research Projects, $5^{\text {th }}$ ed. (New York: Open University Press, 2014), 225.

17 Ibid., 132-133.
} 
tentang konsep Alkitab tentang mahar sekaligus analisis terhadap tradisi belis. Bagian ini menyarankan posisi gereja terhadap belis. Tulisan diakhiri dengan kesimpulan.

\section{Prinsip Belis dalam Agama dan Kebudayaan Marapu}

Pulau Sumba sering disebut Bumi Marapu atau Tanah Marapu. Istilah Marapu (leluhur) mengacu pada pemujaan arwah leluhur yang dihormati karena perannya sebagai pendiri kabisu (suku) orang Sumba, sebagai perantara relasi keturunannya dengan Tuhan, dan sebagai pemberi berbagai prinsip hidup (ritual dan adat) yang efektif menjamin relasi kosmis harmonis yang bermuara pada kesejahteraan. ${ }^{18}$ Prinsip-prinsip hidup yang diturunkan Marapu mempengaruhi seluruh dimensi hidup orang Sumba di seluruh Pulau Sumba.

Marapu adalah agama asli pembentuk seluruh dimensi hidup orang Sumba dan kebudayaan di Pulau Sumba. Agama berkaitan dengan keyakinan terhadap eksistensi maupun peran signifikan berbagai kekuatan supranatural (ciri substantif) dan dengan perannya sebagai pemberi makna hidup dan jawaban bagi persoalan praktis penganutnya (ciri praktis). ${ }^{19}$ Ciri substantif agama Marapu tampak melalui keyakinan akan eksistensi Tuhan dan arwah leluhur (Marapu) yang memperantarai relasi dengan Tuhan. Sementara itu, ciri praktis tampak melalui tekanan pada peran prinsip-prinsip yang diturunkan leluhur untuk menjamin keseimbangan relasi kosmis-harmonis dan kesejahteraan orang Sumba.

Menurut Harari, agama berfungsi mengokohkan tatanan dan struktur masyarakat melalui legitimasi supranatural. ${ }^{20}$ Ini menunjukkan bahwa agama juga memiliki ciri normatif: memberi sistem nilai yang mengatur dan mengokohkan tatanan sosial. Di Sumba, Marapu menurunkan prinsip-prinsip penjamin kesejahteraan yang menjangkau seluruh dimensi hidup dan yang berfungsi menjaga relasi kosmis harmonis dengan Tuhan, leluhur, sesama, dan alam, sehingga orang Sumba terlepas dari malapetaka akibat ketidakseimbangan kosmis. Oleh sebab itu, keseharian orang Sumba distrukturkan oleh sistem nilai Marapu yang dianggap supranatural. Bahkan, prinsip-prinsip Marapu yang supranatural menjadi kategori utama dalam memahami dan merespons realita.

Uraian di atas memberi beberapa petunjuk. Pertama, prinsip-prinsip agama Marapu merupakan komponen utama pembentuk worldview,

\footnotetext{
18 Kamuri, “Menimbang Posisi Penganut Marapu," 80-83.

19 Kevin Schilbrack, “What Isn't Religion?,” The Journal of Religion 93, no. 3 (2013): 293-296.

20 Yuval Noah Harari, Sapiens: A Brief History of Humankind (United Kingdom: McClelland \& Stewart, 2014), 187-188, 202.
} 
bingkai konseptual dalam memahami dan merespons realita. Kedua, karena worldview adalah penentu cara pikir dan cara hidup, maka prinsip-prinsip Marapu tidak dapat tidak menjadi lazim dalam keseharian dan dalam seluruh dimensi hidup orang Sumba. Marapu membentuk kebudayaan di Sumba.

Implikasinya, Marapu merupakan jiwa dan mata air kebudayaan orang Sumba, karena membentuk cara pikir orang Sumba, sehingga realita selalu dipahami dalam kategori-kategori Marapu. Selain itu, Marapu mengondisikan hidup dan kebudayaan yang membentuk tatanan sosial, perilaku individual, serta perilaku komunal orang Sumba. Dengan demikian, Marapu menjadi penentu keunikan identitas budaya orang Sumba yang terekspresi melalui materi budaya maupun berbagai aktivitas budaya (adat atau tradisi $)^{21}$ seperti tradisi belis. Identitas budaya Marapu membedakan orang Sumba dan tradisinya dari kelompok masyarakat lain yang ada di Sumba, NTT, dan daerah lainnya di Indonesia.

Dalam konteks agama Marapu, belis adalah bagian integral dan tidak terpisahkan dari pernikahan yang merupakan peristiwa penting secara sosial dan sakral secara agamawi. Signifikansi pernikahan membuat orang yang belum menikah disebut kaheli nggala wola-uma hakapapa (balai sementara-rumah yang belum selesai). ${ }^{22}$ Frasa ini dapat diinterpretasi sebagai keyakinan bahwa orang yang belum menikah adalah orang yang belum sempurna. Ketidaksempurnaan dapat dikaitkan dengan dua keyakinan. Pertama, secara personal, orang yang tidak menikah belum memiliki penolong dalam menjalankan kehidupan keluarga dan masyarakat. Pernikahan dikaitkan dengan kehadiran pasangan yang berperan sebagai penolong (penyempurna) hidup dan tanggung jawab individual. Kedua, pernikahan berfungsi mengokohkan relasi sosial karena mengikat pria-wanita, orang tua, suku (kabisu), dan kampung (wanno). ${ }^{23}$ Melaluinya, keharmonisan dan kestabilan tatanan sosial dipertahankan karena status sosial individu dan keluarga terjaga dengan baik..$^{24}$ Ini membuat orang yang tidak menikah, secara sosial dianggap belum bisa memperoleh tempat layak dalam

21 Kamuri, “Menimbang Posisi Penganut Marapu," 82-83.

22 Oe. H Kapita, Masyarakat Sumba dan Adat Istiadatnya (Jakarta: BPK Gunung Mulia, 1976), 60.

23 Ibid., 61, 122-123.

24 Fungsi pernikahan sebagai pengikat relasi sosial berkaitan dengan fakta bahwa orang Sumba memiliki tiga strata sosial, yang secara tradisional cenderung dipertahankan: golongan bangsawan dan rato (imam), orang merdeka (orang biasa bukan budak) dan hamba. Status sosial dipertahankan dengan mengusahakan perkawinan di antara strata sosial yang sama, atau larangan menikah dengan orang yang berasal dari strata sosial yang jauh lebih rendah (misalnya: bangsawan dan budak). Bahkan mereka memiliki kabisu (suku, marga) pemberi istri dan kabisu pengambil istri. Setiap anak laki-laki disarankan menikahi wanita dari kabisu pemberi istri, sedangkan setiap anak perempuan disarankan mengambil suami dari kabisu pengambil istri. Melalui penerapan aturan-aturan ini, strata sosial yang dibentuk leluhur dapat dipertahankan. 
pergaulan masyarakat. ${ }^{25}$

Ketidaksempurnaan orang yang belum menikah memiliki kaitan dengan ketiadaan penolong untuk berkontribusi dalam kehidupan sosial dan dalam pencapaian tujuan utama falsafah Marapu yakni keharmonisan relasi kosmis (relasi harmonis dengan dunia bawah (sesama dan alam) dan dunia atas (Tuhan dan Marapu)). Penjelasan di atas menunjukkan bahwa melalui pernikahan, orang Sumba berkontribusi dalam relasi kosmis-harmonis penjamin kesejahteraan manusia.

Namun pernikahan juga penting untuk memelihara relasi harmonis dengan dunia atas karena melaluinya dihasilkan keturunan (anak) penerus nama (marga) Marapu yang juga berperan sebagai penjaga sekaligus pewaris rumah dan pusaka Marapu. ${ }^{26}$ Mereka adalah penerus tradisi dan pelayanan terhadap Marapu melalui ritual dan korban persembahan. Orang yang tidak menikah dianggap belum sempurna karena tidak memiliki penolong untuk memelihara relasi harmonis dengan Marapu. Kegagalan mencapai tujuan Marapu (menikah dan memperoleh keturunan untuk melayani Marapu) membuat mereka tidak memperoleh tempat layak di wanno Marapu (negeri leluhur, surga ${ }^{27}$ sebagai tujuan akhir setelah kematian. Jadi, pernikahan dipahami sebagai pengabdian terhadap Marapu karena melaluinya orang Sumba tidak hanya melahirkan keturunan penerus nama (marga) dan penjaga pusaka Marapu tapi juga mencapai tujuan tertinggi falsafah Marapu yakni relasi kosmis-harmonis penjamin kesejahteraan. Pencapaian tujuan tertinggi itu dikaitkan dengan ketaatan terhadap prinsip-prinsip adat yang diturunkan Marapu.

Jelas bahwa dalam agama dan budaya Marapu pernikahan memiliki peran signifikan (penyempurna manusia secara individual dan sosial) dan sakral (pengabdian terhadap Marapu). Pernikahan tidak hanya menentukan tempat yang layak dalam kehidupan sosial di bumi, melainkan juga dalam kehidupan sesudah kematian. Bahkan, pemaknaan sosial terhadap pernikahan tidak dapat dilepaskan dari dimensi sakral pernikahan, karena konsep kesempurnaan individual dan sosial dalam pernikahan diturunkan dari agama Marapu dan berfungsi untuk memperkuat strata sosial yang ditetapkan dan ingin dipertahankan Marapu $^{28}$ serta memungkinkan relasi kosmis-harmonis penjamin kesejahteraan. Dapat dikatakan bahwa bagi orang Sumba, pernikahan sepenuhnya sakral.

\footnotetext{
25 Kapita, Masyarakat Sumba dan Adat Istiadatnya, 61, 122-123.

26 Silvia Anggraeni dkk., Perempuan Sumba dan Belis, 18.

27 Kapita, Masyarakat Sumba dan Adat Istiadatnya, 60-61, 121-123.

28 Gregory Forth, Rindi: An Ethnographic Study of a Traditional Domain in Eastern Sumba (Leiden: Brill, 1981), 333-334.
} 
Karena signifikansi dan kesakralannya, pernikahan dengan alasan-alasan yang tidak pantas - alasan fisik, romantisme, dan ekonomi - disetarakan dengan sihir yang berpotensi mendatangkan malapetaka. ${ }^{29}$ Malapetaka dapat berupa penyakit, kecelakaan bahkan kematian bagi mempelai maupun anggota keluarga mereka. Bencana seperti kebakaran, hama, dan gempa yang merugikan masyarakat juga dipahami sebagai konsekuensi pelanggaran hukum adat, termasuk aturan-aturan perkawinan. Untuk menghindari hal ini, budaya Marapu memberi peran besar kepada orangtua dan keluarga besar dalam pernikahan. Dikarenakan orang muda dapat dipengaruhi alasan-alasan yang tidak pantas, maka persetujuan dan perjodohan yang dilakukan orangtua sangat menentukan dalam pernikahan.

Persiapan menuju pernikahan melewati dua proses: "masuk minta" (peminangan) dan bayar belis. Sesudah itu, pernikahan sah dan mempelai perempuan dibawa ke rumah mempelai laki-laki (masuk ke dalam kabisu laki-laki). Karena fokus pembahasan adalah belis, maka masuk-minta akan digambarkan secara umum. Masuk minta diawali dengan kedatangan perwakilan keluarga laki-laki ke rumah keluarga perempuan untuk menyatakan tujuannya (melamar) dengan membawa barang bawaan yang disebut kuda ketuk pintu. Jika lamaran diterima, keluarga perempuan memberi pemberian balasan.

Setelah itu, keluarga perempuan mengumpulkan kabisu-kabisu terkait untuk menunjukkan bukti keseriusan keluarga laki-laki (pemberian-pemberiannya) dan membicarakan persiapan pernikahan. Hal yang sama akan dilakukan keluarga laki-laki dan kabisu-kabisu terkait. Umumnya, keluarga memusyawarahkan peran dan kontribusi masing-masing dalam pernikahan. Hal ini berkaitan dengan fakta bahwa setiap perjumpaan senantiasa melibatkan pertukaran pemberian yang seimbang nilainya. Keluarga laki-laki memberi hewan (seperti kuda dan kerbau) dan mamuli (perhiasan emas atau perak berbentuk organ genitalia perempuan). Sementara itu, keluarga perempuan memberi barang-barang seperti tenunan untuk laki-laki, sarung dan pakaian tradisional perempuan. Jumlah barang yang diberikan bervariasi sesuai status sosial dan kesepakatan.

Musyawarah keluarga perempuan juga membicarakan nilai belis atau seperangkat mas kawin (mahar) yang harus dibayarkan keluarga pengambil perempuan. Orang Sumba mengenal tiga macam belis ${ }^{30}$ yakni pertama, belis yang sakral karena dipersembahkan pada Marapu kabisu pemberi perempuan sehingga Marapu mengizinkan mempelai perempuan keluar

\footnotetext{
Ibid., 333, 456

30 John R. Lahade, Perempuan, Kuda dan Tenun: Kedudukan Perempuan dalam Keluarga di Masyarakat Wewewa, Sumba (Salatiga: Widya Sari Press, 2011), 98-99.
} 
dari kabisu-nya dan masuk ke dalam kabisu suaminya. Kedua, pokok belis atau belis utama yang diberikan pada orangtua mempelai wanita sebagai "pengganti anak" dan pengikat tali kekeluargaan. Ketiga, belis tambahan yang nilainya bergantung negosiasi dua keluarga. Belis ini ditentukan keluarga perempuan berdasarkan status sosial dan kemampuan mereka untuk memberi balasan yang seimbang kepada keluarga laki-laki. Falsafah di balik praktik belis adalah keseimbangan kosmis di mana ada kesimbangan relasi spiritual dengan Marapu dan relasi sosial setiap kabisu yang terlibat dalam pernikahan.

Setelah ditentukan keluarga perempuan, nilai belis disampaikan pada keluarga laki-laki. Jika nilai belis disetujui, penikahan sah. ${ }^{31}$ Keluarga lakilaki menunjukkan pokok belis kepada perwakilan yang akan dibawa pulang oleh perwakilan keluarga perempuan, sementara sisanya diserahkan pada hari mempelai perempuan dijemput oleh keluarga laki-laki untuk dibawa pulang dan masuk ke dalam kabisu keluarga laki-laki.

Di satu sisi, pernikahan adalah peristiwa sakral yang tidak boleh terjadi dengan motif ekonomi, sehingga bagi laki-laki yang miskin sekalipun, orang Sumba harus mempersiapkan istri. ${ }^{22}$ Di sisi lain, pernikahan mempersyaratkan belis, sehingga tanpa belis pernikahan dapat ditunda atau dibatalkan. ${ }^{33}$ Agar kedua tuntutan Marapu tersebut dapat digenapi, leluhur orang Sumba menentukan jalan tengah, sehingga nilai belis dapat dinegosiasikan sesuai kondisi keluarga laki-laki. Bahkan, menurut mitos, nilai belis yang wajib dibayarkan adalah dua ekor kuda. ${ }^{34}$

Jelas bahwa dalam tradisi yang diturunkan Marapu, belis adalah prasyarat pernikahan yang tidak boleh ditiadakan. Oleh sebab itu, di satu-sisi, laki-laki yang paling miskin sekalipun harus membayar belis dan di sisi lain, nilai belis dapat dinegosiasikan, bahkan leluhur menentukan nilai yang terjangkau oleh orang miskin. Pembayaran belis seperti ini tidak merugikan keluarga laki-laki maupun keluarga perempuan, karena pemberian balasan dari keluarga perempuan bernilai seimbang dengan belis. Pertukaran pemberian yang seimbang ini menunjukkan bahwa belis bukan proses ekonomi berupa pertukaran perempuan dengan sejumlah uang atau materi.

Perempuan tidak sedang diperlakukan sebagai objek yang diperdagangkan dalam tradisi belis. Lahade bahkan menunjukkan bahwa pemberian balasan (dari keluarga perempuan) yang bernilai seimbang dengan belis merupakan petunjuk bahwa perempuan bernilai setara dengan

\footnotetext{
Forth, Rindi: An Ethnographic Study of a Traditional Domain in Eastern Sumba., 335.

Ibid., 333.

Wara, Yanuarius L., Widianto, Tri., Purwiyastuti, Tradisi Belis, 3-4.

Boersema, Perjumpaan Injil dan Budaya dalam Kawin-Mawin, 105.
} 
JOHANIS PUTRATAMA KAMURI \& GRACE MARIANY TOUMELUK

laki-laki. ${ }^{35}$ Kesimpulan ini dapat diterima karena dalam cara pikir orang Sumba, perempuan memang ditempatkan pada posisi terhormat seperti laki-laki. Hal ini bahkan berlaku dalam wilayah yang dianggap sakral. Tuhan yang menciptakan alam semesta dipahami sebagai pribadi yang transenden dan suci sehingga tidak boleh disebut nama-Nya. Sebab itu Tuhan disebut Ama a Malowo-Ina a Marawi (Bapak yang memintal-Ibu yang menenun). Selain itu struktur bagian tengah rumah adat yang sangat sakral memiliki dua bagian yang diasosiasikan dengan laki-laki dan perempuan. Posisi terhormat perempuanlah yang memungkinkan sebutan Ina a Marawi diberikan pada Tuhan dan bagian sakral pada rumah adat diasosiasikan dengan perempuan.

Pertanyaannya adalah: mengapa belis begitu penting dan bermakna bagi orang Sumba, sehingga dalam kondisi termiskin pun, keluarga lakilaki harus mengusahakannya? Belis memiliki beberapa fungsi: ${ }^{36}$ pertama, makna religius. Belis adalah pemberian bagi Marapu keluarga perempuan. Hal ini dilakukan untuk menjaga keseimbangan kosmos karena perempuan dikeluarkan dari sukunya dan dimasukkan dalam kabisu laki-laki. Pemberian-pemberian ini mengisi tempat kosong yang ditinggalkan mempelai perempuan di dalam keluarganya, sekaligus untuk menenangkan dan memperoleh izin Marapu keluarga perempuan.

Kedua, makna sosial. Nilai belis tambahan menandai status sosial pihak-pihak yang terlibat dalam perkawinan sedangkan belis pokok menandai sahnya perkawinan dan penghargaan terhadap orangtua dan keluarga (diwakili paman dari pihak ibu) yang telah membesarkan dan mendidik mempelai perempuan. Bahkan belis menjadi pengikat relasi kabisu pemberi perempuan dan kabisu pengambil perempuan. Ini berarti, belis merupakan tanda yang tidak hanya mempersatukan sepasang mempelai, tetapi keseluruhan komponen yang terkait padanya.

Dua pemaknaan di atas menunjukkan bahwa tujuan belis bukan keuntungan ekonomis. Belis adalah ekspresi falsafah Marapu yang bertujuan untuk menciptakan relasi kosmis-harmonis yakni keseimbangan relasi dengan dunia atas (Tuhan dan Marapu) dan dunia bawah (dengan sesama, bahkan dengan alam) yang memungkinkan kesejahteraan sehingga belis dikaitkan dengan penghormatan dan relasi mempelai, kabisu terkait, dan Marapu dari setiap kabisu.

\footnotetext{
Lahade, Perempuan, Kuda dan Tenun, 98.

36 Bdk. Forth, Rindi: An Ethnographic Study of a Traditional Domain in Eastern Sumba, 362, 365; Silvia Anggraeni dkk., Perempuan Sumba dan Belis, x, 3; dan Boersema, Perjumpaan Injil dan Budaya dalam Kawin-Mawin, 103-104, 108-109.
} 


\section{Sikap Gereja terhadap Kebudayaan}

Alkitab mendeskripsikan kehidupan Kristen sebagai pengembaraan (bdk. Kejadian 47:8-9; Ibrani 11: 8-16). Sebagian orang Kristen memahami pengembaraan sebagai persinggahan di mana perjuangan dalam dunia tidak signifikan dan cacat. ${ }^{37}$ Mereka mengasumsikan ketidakmungkinan untuk menghasilkan kebudayaan yang benar dan menekankan oposisi iman dan kebudayaan sehingga keduanya tampak sebagai dua entitas yang senantiasa bertentangan dan tidak mungkin memiliki titik temu. Akibatnya adalah ketidakpedulian terhadap kebudayaan dan usaha melarikan diri dari padanya ${ }^{38}$ sehingga orang Kristen tidak dapat memberi kontribusi positif di dalam dunia.

Sikap ini bertentangan dengan mandat budaya yang mendorong manusia berkontribusi bagi dunia melalui kebudayaan (Kejadian 1:26-30). Keberdosaan tidak meniadakan mandat ini sebab kebudayaan - jika didefinisikan sebagai totalitas aktivitas manusia dan hasil-hasilnya ${ }^{39}$ - tidak dapat dihindari karena melaluinya manusia bertahan hidup. Selain itu mandat budaya juga berfungsi untuk memuliakan Allah. Dengan demikian mandat budaya tidak dapat dipenuhi tanpa penggenapan mandat Injil karena pelaksanaan mandat budaya tidak hanya berkaitan dengan tata kelola dunia tetapi juga menata dunia berdasarkan prinsip-prinsip Kerajaan Allah.

Maka, keterlibatan gereja dalam kebudayaan bukan keterlibatan pasif, seperti yang digambarkan Niebuhr sebagai tindakan penyesuaian diri pada kebudayaan dengan menyingkirkan prinsip-prinsip iman Kristen. ${ }^{40}$ Oleh sebab itu, Yesus mengutus gereja ke dalam dunia dengan menggunakan dua gambaran. Pertama, gereja diutus seperti domba ke tengah serigala, sehingga mereka harus cerdik seperti ular dan tulus seperti merpati (Matius 10: 16-18). Menurut Kamuri ${ }^{41}$, ini adalah petunjuk bahwa situasi dunia dan kebudayaannya tidak ideal, bahkan berbahaya. Namun, Allah justru mendorong orang Kristen untuk masuk ke dalam masyarakat dan kebudayaan, berusaha memahaminya, dan melampaui situasi tersebut dengan cerdik (melalui penggunaan strategi yang tepat).

Strategi cerdik gereja dalam situasi tidak ideal dibatasi oleh prinsip-prinsip kebenaran dalam Alkitab (wahyu khusus) maupun dalam kitab alam (wahyu umum). Ini sesuai agenda Yesus, yaitu menghadirkan Kerajaan

37 Jim West, “The Distinctivenes of 'Two Kingdoms' Theology," Unio Cum Christo 4, no. 1 (2018): 143.

38 Johanis Putratama Kamuri, "Yesus dan Machiavelli: Moralitas, Religiusitas, dan Kompetensi Politisi di Ruang Publik," Societas Dei: Jurnal Agama dan Masyarakat 06, no. 2 (2020): 169.

39 Richard Niebuhr, Christ and Culture (New York: Harper \& Row, Publishers, Inc., 1953), 32.

$40 \quad$ Ibid., 40-43.

41 Kamuri, "Yesus dan Machiavelli," 180-181. 
Allah yang tidak berasal dari dunia (Yohanes 18:36) melainkan bagi dunia ${ }^{42}$ sehingga seluruh dimensi hidup di dalamnya mengalami transformasi berdasarkan prinsip-prinsip Kerajaan Allah. Ini adalah keterlibatan aktif di mana orang Kristen mengakui paradoks iman dan budaya karena dosa mempengaruhi budaya sekaligus menegaskan bahwa orang Kristen tidak dipisahkan dari kebudayaan karena Kristus memiliki kuasa untuk mentransformasi manusia dan budaya. ${ }^{43}$

Hal ini berkaitan dengan gambaran kedua, yakni peran gereja sebagai garam dan terang. Sebagaimana garam dan terang sangat dibutuhkan, sehingga tidak boleh tidak ada di zaman Yesus, demikian juga orang Kristen harus hadir dalam masyarakat dan kebudayaan sebagai saksi. Sebagaimana garam merupakan pengawet dan pencegah kebusukan, demikian juga gereja hadir dalam kebudayaan sebagai antiseptik yang menyingkirkan kekotoran atau kejahatan. ${ }^{44} \mathrm{Jadi}$, kebudayaan bukan entitas yang tidak memiliki hubungan dengan kehidupan Kristen. Gereja adalah pengembara yang mengemban misi Allah untuk masuk ke dalam masyarakat dan melakukan transformasi.

Teladan utama transformasi budaya adalah Yesus yang berinkarnasi untuk menyatakan Kerajaan Allah dalam dunia. ${ }^{45}$ Ini berarti, gereja hadir dalam kebudayaan untuk menyatakan Kerajaan Allah dengan tetap mewaspadai pengaruh dosa terhadap kebudayaan, tanpa terjebak dalam oposisi total terhadapnya. Ini menuntut tiga kesadaran gereja. Pertama, kebudayaan adalah berkat, karena bersumber dari perintah Allah untuk mengelola alam dan menjawab berbagai kebutuhan melalui hasil-hasilnya. Manusia harus mengelola alam (berkebudayaan) agar dapat bertahan hidup. Oleh sebab itu, Laugrand menunjukkan berbagai prinsip dalam agamaagama kuno yang serupa dengan prinsip-prinsip yang diperjuangkan oleh kekristenan dan modernisme. ${ }^{46}$ Ini dimungkinkan oleh wahyu umum Allah kepada manusia (alam dan hati nurani) yang melaluinya manusia dapat memahami kebenaran umum (Roma 2:14-15) dan mengonstruksi kebudayaan yang dapat disyukuri orang Kristen. Dengan demikian, kebudayaan dapat dipahami sebagai berkat Allah.

Fakta ini mendorong gereja untuk masuk dan terlibat dalam masyarakat dan kebudayaan. Meski demikian, gereja harus memiliki kesadaran selanjutnya, yaitu kewaspadaan terhadap pengaruh dosa dalam kebudayaan yang

43 Niebuhr, Christ and Culture, 43.

44 William Barclay, Pemahaman Alkitab Setiap Hari (terj.) (Jakarta: BPK Gunung Mulia, 2015), 198-200.

45 D.A. Carson, Kristus dan Kebudayaan: Sebuah Kajian Baru (Surabaya: Momentum, 2018), 54-62.

46 Frédéric Laugrand, "The Transition to Christianity and Modernity among Indigenous Peoples," Reviews in Anthropology 41, no. 1 (2012): 1-22. 
merupakan eksternalisasi pikiran yang tercemar oleh dosa. Kewaspadaan memungkinkan keterlibatan tanpa kompromi terhadap prinsip-prinsip budaya yang berdosa atau penyesuaian total prinsip-prinsip iman terhadap kebudayaan. ${ }^{47}$

Ketiga, transformasi merupakan tindakan aktif untuk masuk dalam kebudayaan, berusaha memahami kebudayaan dengan benar, mengakomodasi hal-hal yang tidak bertentangan dengan firman Allah dan dapat menjadi berkat bagi manusia, serta mengkritik hal-hal yang bertentangan dengan Firman. ${ }^{48}$ Melaluinya, kebudayaan tidak hanya ditolak melainkan juga diakomodasi atau dimodifikasi sesuai kebenaran Firman. Jadi transformasi kebudayaan tidak dicapai dengan menarik diri dari kebudayaan, atau menyesuaikan diri terhadap kebudayaan tanpa sikap kritis, atau mengganti seluruh prinsip kebudayaan dengan prinsip iman Kristen. Sebaliknya transformasi dicapai dengan mempelajari kebudayaan, menolak hal-hal yang bertentangan dengan kebenaran Alkitab, dan mengakomodasi unsur-unsur budaya yang dapat diterima karena tidak bertentangan dengan Alkitab.

\section{Memahami Konsep Mahar dalam Alkitab}

Mahar atau belis tidak jahat atau berdosa pada dirinya. Alkitab mengindikasikan bahwa hal ini merupakan proses umum dalam sebuah perencanaan pernikahan, bahkan diterima dan diatur Allah untuk dipraktikkan dalam kehidupan umat-Nya (Keluaran 22:16-17 dan 1 Samuel 18:25). Beberapa pemaknaan terhadap mahar dalam Alkitab akan dipaparkan berdasarkan analisis penulis terhadap kisah peminangan Ribka bagi Ishak dalam Kejadian 24. Berdasarkan analisis tersebut, penulis mendeskripsikan sejumlah persamaan dan perbedaan antara konsep mahar dalam Alkitab dan konsep belis di Sumba.

Dalam proses menemukan istri bagi Ishak, Eliezer - hamba Abraham - membawa sepuluh unta dan barang-barang berharga sebagai mahar dengan nilai sangat besar. ${ }^{49}$ Karena pemberian yang sangat mahal ini tidak dapat tidak menunjukkan status sosial dan kekayaan Abraham, maka pertanyaannya: apakah mahar dalam Alkitab merupakan penanda status sosial dan prestise pemberi mahar? Selanjutnya, apakah ini merupakan prinsip normatif yang harus diteladani orang Kristen masa kini, khususnya orang Kristen Sumba?

\footnotetext{
47 Paige Patterson, "Encountering Culture in Light of The Book of Daniel," Southwestern Journal of Theology 55, no. 1 (2012): 57.

48 Kamuri, "Transformasi Wawasan Dunia Marapu," 136-138.

49 Victor P. Hamilton, The New International Commentary on the Old Testament: The Book of Genesis Chapter 18-50, ed. R.K. Harrison and Robert L. Hubbard Jr. (Grand Rapids, Michigan: William. B. Eerdmans Publishing Company, 1995), 144.
} 
Dalam Kejadian 24, Eliezer berada dalam konteks yang tidak biasa, karena harus menjumpai calon mempelai perempuan dan keluarga yang (sangat mungkin) tidak pernah dikenal dan tidak pernah mengenal Abraham, tuannya. Penegasan status sosial dibutuhkan untuk memenangkan hati Ribka dan memberi kesan positif pada keluarganya. ${ }^{50}$ Dengan demikian, Ribka diharapkan berkenan mengikuti Eliezer ke rumah Abraham, dan keluarganya diyakinkan untuk melepas anak perempuannya dalam situasi yang tidak biasa tersebut. Penggunaan mahar sebagai penegasan status sosial memiliki keserupaan dengan makna sosial belis, khususnya belis tambahan. Tapi penanda status sosial bukan makna utama mahar dalam Alkitab sehingga dimunculkan dalam situasi tidak biasa. Ini juga serupa dengan belis tambahan sehingga nilainya dapat dinegosiasikan.

Dalam situasi normal, pemberian Eliezer dapat dipahami sebagai ekspresi penghormatan kepada Ribka (ayat 22), terutama untuk kualitas jiwanya yang mengagumkan sebagaimana diperlihatkannya dalam sikap terhadap Eliezer dan unta-unta yang dibawanya. ${ }^{51}$ Selain itu, Eliezer juga menyerahkan sejumlah pemberian kepada saudara dan ibu Ribka (ayat 53). Mahar diberikan karena keluarga perempuan kehilangan pelayanan dari anak perempuannya dan keturunan potensial yang akan dilahirkannya. ${ }^{52}$ Jika memperhatikan konteks Kejadian 24:16a dan sejumlah teks Perjanjian Lama lainnya (a.1 Kejadian 34:13 dan Keluaran 22:16), kemungkinan pemberian mahar ini terkait juga dengan status keperawanan Ribka. Ini berarti, pemberian tersebut tidak dipahami sebagai nilai ekonomis seorang perempuan, melainkan sebagai penghargaan terhadap Ribka dan keluarganya yang telah menjaga kesucian Ribka. Makna utama mahar (penghargaan terhadap perempuan dan keluarganya) berpadanan dengan makna pokok belis sebagai tujuan utama dalam makna sosial belis. Keserupaan konsep mahar dalam Alkitab dan belis di Sumba adalah keduanya tidak menjadi penanda nilai ekonomis perempuan.

Mahar dalam Alkitab tidak dipahami secara sempit sebagai penanda status sosial dan prestise pemberinya. Meski tidak dapat tidak menunjukkan status sosial atau prestise pemberinya, harus ditegaskan bahwa ini bukan tujuan utama pemberian mahar dalam Alkitab. Mahar yang diberikan Abraham dapat dipahami sebagai pemberian terbaik bagi Ribka dan keluarganya berdasarkan kemampuan maksimal keluarga laki-laki. Ini adalah ekspresi penghormatan maksimal terhadap Ribka dan keluarganya. Perlu

Bruce K. Waltke and Cathi J. Fredricks, Genesis: A Commentary (Grand Rapids, Michigan: Zondervan, 2001), 328-329.

51 Waltke and Fredricks, "Genesis: A Commentary," 328-329.

$52 \quad$ Ibid., 331. 
juga ditekankan bahwa makna sosial belis sebenarnya memiliki keserupaaan dengan konsep mahar dalam Alkitab tersebut.

\section{Penanda Penghormatan Tertinggi bagi Perempuan dan Keluarganya}

Uraian di atas menunjukkan bahwa, berdasarkan Kejadian 24, poros utama konsep mahar adalah penghormatan terhadap calon mempelai perempuan dan keluarganya. Dengan demikian, sejumlah kesimpulan dapat diambil untuk mendeskripsikan persamaan dan perbedaan konsep belis dari konsep mahar dalam Alkitab. Pertama, pembayaran mahar dapat dikaitkan dengan penghormatan terhadap keluarga calon mempelai perempuan yang kehilangan pelayanan anak perempuan yang telah dididik dan dibesarkan dengan baik. Hal ini serupa dengan fungsi pokok belis untuk menegaskan penghormatan terhadap keluarga perempuan dengan mengisi kekosongan karena kepergian anak perempuan dan menjaga relasi harmonis dua keluarga. Meski demikian, mahar dalam Alkitab bukan ekspresi penghormatan terhadap leluhur keluarga perempuan karena mahar tidak bertujuan memperoleh izin dan berkat arwah leluhur sebagaimana tampak pada makna religius belis. Sebab itu makna sosial belis dapat diterima sebagai unsur yang berguna dalam agenda transformasi budaya dan dapat dipraktikkan orang Kristen Sumba dengan terlebih dahulu menyingkirkan makna religiusnya.

Kedua, meski tidak dapat dilepaskan begitu saja dari prestise dan status sosial pemberi, tujuan dan makna utama mahar di dalam Alkitab, sebagaimana dicontohkan dalam Kejadian 24 adalah penanda penghormatan tertinggi terhadap mempelai perempuan dan keluarganya. Jadi, berbeda dengan konsep belis tambahan yang menekankan status sosial dan prestise sebagai tujuan utama di balik makna sosialnya: konsep mahar dalam Alkitab tidak menjadikan status sosial dan prestise sebagai tujuan utama. Sebab itu belis tambahan yang menekankan prestise sosial tidak perlu menjadi fokus praktik belis. Orang Sumba Kristen memiliki dua kemungkinan dalam penerapan belis tambahan yakni meniadakannya atau - sebagaimana terdapat dalam tradisi belis itu sendiri (jalan tengah yang ditawarkan leluhur) - menegosiasikannya sehingga tidak memberatkan pihak-pihak yang terlibat dalam pernikahan.

Konsep sosial belis juga memiliki keserupaan dengan konsep mahar yang menekankan penghormatan tertinggi terhadap mempelai perempuan dan keluarganya. ${ }^{53}$ Perempuan diperlakukan sebagai subjek, yakni tujuan

53 Pemberian mas kawin tidak menyatakan bahwa sang istri telah dijual kepada suaminya dan menjadi miliknya. Bahkan Perjanjian Lama menunjukkan kebiasaan membeli seorang hamba perempuan untuk menjadi istri seorang laki-laki. Hukum-hukum seperti itu bertujuan melindungi wanita dari siksaan 
mahar atau belis, bukan sebagai objek atau alat pertukaran demi keuntungan ekonomi. Perempuan justru ditempatkan pada posisi terhormat dalam tradisi mahar dan belis. Salah satu petunjuk bahwa belis bukan praktik jual-beli perempuan adalah pemberian timbal-balik antara dua keluarga yang terlibat dalam pernikahan. Hal yang sama tampak juga di dalam Alkitab melalui tindakan ayah mempelai perempuan yang memberikan anaknya sebagai hadiah perkawinan, seperti yang dilakukan oleh Kaleb (Yosua 15:15-19) atau Firaun yang memberi kota Gezer sebagai hadiah perkawinan kepada anak perempuannya yang dinikahi Salomo (1 Raja-raja 9:16). Pemberian pihak perempuan ini bahkan dapat lebih tinggi nilainya dari mahar yang diberikan laki-laki. Ketiadaan motif ekonomi mencegah perlakuan sewenang-wenang terhadap istri (perempuan).

\section{Penghormatan Tertinggi tidak Ditentukan Nilai Mahar atau Belis}

Telah ditunjukkan bahwa nilai mahar yang diberikan Abraham sangat tinggi. Meski diberikan dalam wujud berbeda, beberapa catatan Alkitab lain menunjukkan hal yang sama. Yakub membayar mahar untuk Rahel dengan bekerja selama 7 tahun pada Laban (Kejadian 29:18-20), sementara Daud memberi seratus kulit khatan orang Filistin sebagai mahar untuk Mikhal (1 Samuel 18:25, 27). Ketiga catatan tentang nilai mahar yang sangat tinggi ini dapat memberi kesan normatif yakni penghargaan tertinggi kepada perempuan dan keluarganya dalam sebuah proses pernikahan Alkitab harus diekspresikan melalui mahar yang bernilai sangat tinggi.

Namun konteks tiga peristiwa tersebut perlu diperhatikan sebelum berkesimpulan. Eliezer dibekali mahar bernilai tinggi dalam konteks unik yang dijelaskan sebelumnya. Eliezer tidak tahu siapa yang akan dilamar dan dijadikan istri bagi Ishak. Nilai mahar yang diberikan bertujuan membuka jalan dan meyakinkan calon mempelai perempuan maupun keluarganya yang tidak dikenal. Sementara itu, Laban adalah ayah yang materialistis (Kejadian 24:29-30), yang keputusan-keputusannya cenderung digerakkan oleh motif ekonomi ${ }^{54}$, sehingga rela memperlakukan anaknya sebagai komoditas (Kejadian 31:14-16). Nilai mahar yang tinggi merupakan strategi ekonomi Yakub yang tidak memiliki apa-apa untuk ditawarkan sebagai mahar, untuk menarik hati Laban dan memastikan pernikahannya. Motif ekonomi pada Yakub dan Laban merupakan motif yang tidak sesuai dengan konsep mahar dalam bagian lain Alkitab. Ketidaksesuaian juga tampak dalam kisah Daud, karena mahar bernilai tinggi tersebut dimaksudkan

atau penganiayaan, bukan menjadikannya sebagai alat pertukaran (Kel. 21:7-11); J.I. Packer, Merrill C. Tenney, and William White, Jr., Ensiklopedi Fakta Alkitab 2 (terj.) (Malang: Gandum Mas, 2009), 895.

54 Waltke and Fredricks, Genesis: A Commentary, 330. 
Saul untuk membunuh Daud. Konteks yang tidak biasa dan motif berdosa tidak dapat dijadikan rujukan utama untuk menetapkan nilai belis yang sangat tinggi, seolah-olah Allah menghendaki agar penghormatan dalam pernikahan ditunjukkan melalui nilai belis atau mahar yang tinggi itu.

Keluaran 22:17 mengindikasikan keharusan mahar sebagai penanda penghormatan. Namun, teks tersebut tidak menentukan jumlah mahar. Nilai mahar yang tinggi justru ditentukan sebagai denda terhadap berbagai kasus di mana kesucian pernikahan ternodai (Keluaran 22:16 dan Ulangan 22:28-29). Nilai dan bentuk mahar, yang tidak ditentukan, memungkinkan fleksibilitas dan negosiasi sehingga tidak merugikan pihak-pihak yang terlibat dalam pernikahan (yang dalam Efesus 5:22-33 ditegaskan sebagai lembaga yang mulia sehingga digunakan Paulus sebagai analogi relasi gereja dengan Kristus). Fleksibilitas dan negosiasi tampak melalui pemberian yang variatif atau tidak seragam. ${ }^{55}$ Situasi seperti ini memungkinkan keluarga laki-laki untuk mengekspresikan penghormatan tertinggi terhadap perempuan dan keluarganya dengan memberi mahar terbaik berdasarkan kemampuannya.

Tradisi belis juga menunjukkan ciri yang sama. Belis harus diberikan sebagai penghormatan terhadap perempuan dan keluarganya. Namun, pernikahan adalah kehendak Marapu, sehingga orang miskin pun harus diberi kemungkinan untuk menikah. Dengan demikian, nilai belis minimal (dua ekor kuda) ditentukan melalui mitos (narasi otoritatif pemberi prinsip hidup bagi orang Sumba) dan dapat dinegosiasikan sesuai kemampuan keluarga laki-laki. Ini berarti bahwa tingginya nilai belis tidak menentukan kualitas penghormatan terhadap perempuan dan keluarganya. Pemberian terbaik dalam batas-batas kemampuan keluarga laki-laki dan perempuan adalah ekspresi penghormatan dimaksud.

\section{Pergeseran dan Distorsi Konsep Belis di Sumba}

Uraian tentang makna tradisi belis dan perbandingan dengan makna mahar dalam Alkitab menunjukkan bahwa tradisi belis tidak sepenuhnya bermasalah bagi orang Kristen, apalagi negatif pada dirinya. Harus diakui bahwa praktik belis untuk menghormati dan memperoleh restu leluhur yang sudah mati (makna religius) tidak bersesuaian dengan prinsip pernikahan atau mahar dalam Alkitab sehingga harus ditolak. Selain itu, pemaknaan sosial terhadap belis tambahan yang menekankan status sosial dan prestise keluarga juga tidak sesuai dengan prinsip Alkitab dan dapat menyebabkan sejumlah persoalan sosial, seperti eksploitasi nilai belis untuk menunjukkan

\footnotetext{
55 Packer, Tenney, and White, Jr., Ensiklopedi Fakta Alkitab 2, 893, 895.
} 
atau mengangkat status sosial dan prestise keluarga. Nilai belis yang sangat tinggi merupakan konsekuensi logisnya. Hal ini mengakibatkan kemiskinan, utang yang sangat besar, dan kerenggangan relasi bahkan konflik berkepanjangan antara keluarga laki-laki dan perempuan karena merasa dirugikan.

Meski demikian, pemaknaan religius dan sosial terhadap belis tampaknya disiapkan leluhur untuk mengantisipasi situasi ini karena kedua pemaknaan tersebut menekankan penghormatan terhadap leluhur, perempuan, dan keluarganya serta peran belis untuk mengikat relasi dua keluarga besar. Karena falsafah Marapu sangat menekankan keseimbangan kosmis, kemungkinan dua pemaknaan ini diberikan untuk mengimbangi potensi negatif yang termuat dalam pemaknaan sosial. Maka dapat dikatakan bahwa secara sosial, berbagai persoalan terkait praktik belis di Sumba sebagaimana dipaparkan pada awal tulisan ini - tidak bersumber dari prinsip leluhur di balik tradisi belis itu sendiri, melainkan bersumber dari pergeseran dan distorsi terhadap makna belis yang diberikan leluhur.

Persoalan ini dapat dikaitkan dengan beberapa hal. Pertama, pergeseran makna belis dan berkurangnya komitmen pelaku tradisi terhadap prinsip-prinsip agung dan seimbang yang melatarbelakangi tradisi ini. ${ }^{56}$ Ini membuat pelaku tradisi belis sangat menekankan aspek sosial tradisi ini (prestise dan status sosial) dan menjadikannya sebagai tujuan utama dalam negosiasi nilai belis, tanpa mengimbanginya dengan pengertian, penekanan, dan penerapan makna religius dan sosial. Bahkan dalam kondisi tertentu, dua prinsip penyeimbang tersebut justru dieksploitasi dan digunakan untuk memperoleh prestise dan status sosial tinggi yang diharapkan (dengan menetapkan nilai belis yang sangat tinggi).

Kedua, distorsi tradisi belis oleh motif ekonomi. Tidak jarang keuntungan ekonomis yang ingin diperoleh melalui penetapan nilai belis yang sangat tinggi telah mengubah praktik belis. ${ }^{57}$ Motif ekonomi mendorong eksploitasi terhadap tradisi belis dan prinsip-prinsip di belakangnya. Tradisi dan prinsip-prinsip tersebut justru digunakan sebagai alasan untuk menetapkan nilai belis yang sangat tinggi. Motif ekonomi ini tidak hanya berdampak pada nilai belis, tetapi juga terhadap status dan nasib perempuan di Sumba. Motif ekonomi menurunkan nilai perempuan ke tataran objek dan komoditas (alat ekonomi). Tidak heran jika tradisi belis cenderung dipahami secara negatif sebagai proses jual-beli perempuan. Hal ini jauh dari pemaknaan asali yang diberikan leluhur terhadap belis. Dampak penurunan nilai perempuan dan persepsi negatif terhadap belis adalah perlakuan sewenang-wenang terhadap perempuan (istri) yang dianggap

6 Silvia Anggraeni dkk., Perempuan Sumba dan Belis, x, 2-3.

57 Silvia Anggraeni dkk., Perempuan Sumba dan Belis, $x, 2-3$. 
sudah lunas dibayar. Kekerasan terhadap perempuan adalah konsekuensi logisnya.

Pergeseran makna dan distorsi belis oleh motif ekonomi membuat harga belis sangat tinggi. Ini mengakibatkan kemiskinan, kekerasan, dan konflik. Keharmonisan, yang menjadi cita-cita tertinggi leluhur orang Sumba melalui praktik belis, justru tidak dicapai bahkan dirusak dalam pelaksanaan tradisi yang sama. Kehadiran Kristen seharusnya menghasilkan transformasi. Namun, orang Kristen Sumba menghadapi perosalan ketiga: kurangnya pemahaman terhadap prinsip Alkitab tentang mahar yang dapat memurnikan praktik belis melalui transformasi (mempertahankan prinsip-prinsip agung, mengeliminasi prinsip-prinsip yang bertentangan dengan Alkitab, dan membersihkan distorsi untuk mengembalikan tradisi belis ke bentuk semula).

Kurangnya pengertian terhadap prinsip mahar dalam Alkitab membuat orang Kristen kehilangan kemampuan untuk bersikap kritis terhadap budaya belis yang masih dipraktikkannya. Akibatnya, orang Kristen Sumba menerima dan menerapkan prinsip-prinsip yang tidak sesuai dengan Alkitab dan tidak dapat mempertahankan prinsip-prinsip agung dalam tradisi belis. Ketidakmengertian juga memungkinkan orang Kristen menerapkan praktik belis yang terdistorsi atas nama tradisi, bahkan (tanpa analisis teliti) memanfaatkan teks-teks Alkitab yang dianggap berkaitan dengan mahar sebagai fondasi untuk mendukung praktik belis yang salah.

Berdasarkan perspektif Kristen, persoalan dalam praktik belis di Sumba tidak bersumber pada prinsip-prinsip kafir dan primitif. Persoalan ini berkaitan dengan kegagalan orang Kristen untuk menghadirkan transformasi berdasarkan pengertian yang benar terhadap konsep belis dan mahar. Dikarenakan orang Kristen adalah penduduk mayoritas di Pulau Sumba, maka kegagalan transformasi tradisi belis dan keterlibatan orang Kristen dalam praktik belis yang menyimpang dari nilai leluhur akan menyebabkan pergeseran yang semakin jauh dan distorsi yang semakin masif.

Transformasi hanya terjadi jika orang Kristen Sumba, sebagai penduduk mayoritas di Pulau Sumba, bersikap tepat terhadap tradisi belis. Sikap yang tepat dihasilkan melalui sikap kritis yang memungkinkan moderasi dalam praktik belis. Moderasi memungkinkan orang Kristen untuk tetap mempraktikkan belis tanpa terjebak dalam distrosi dan pelaksanaan prinsip yang bertentangan dengan ajaran Alkitab.

\section{Kesimpulan dan Saran}

Sebelum menentukan sikap yang tepat terhadap budaya belis di Sumba orang Kristen harus meletakkan dan memahami praktik belis dalam konteks 
agama dan kebudayaan Marapu serta prinsip-prinsip Alkitab tentang mahar. Keputusan diambil dengan menjadikan kebenaran Alkitab sebagai bingkai konseptual untuk mengkritik kebudayaan. Prinsip-prinsip belis yang tidak menentang Alkitab atau tidak merugikan manusia dan kemanusiaaan tidak perlu ditolak. Prinsip-prinsip belis yang bertentangan dengan Alkitab dan kemanusiaan harus disesuaikan kepada kebenaran Alkitab. Hasilnya adalah modifikasi atau perubahan.

Meski demikian, orang Kristen Sumba perlu menghindari penerimaan tanpa sikap kritis terhadap praktik belis yang dilatarbelakangi falsafah Marapu. Orang Kristen tidak dapat menerima makna religius di balik tradisi belis yakni penghormatan terhadap leluhur yang berkuasa memberi restu dan berkat pada pernikahan keturunannya. Belis harus didedikasikan kepada orang-orang yang hidup sebagai tanda penghormatan. Sementara makna sosial belis tambahan harus dikritik karena menekankan prestise dan status sosial pemberi dan penerima belis menjadi tujuan dalam nilai belis. Orang Kristen dapat meniadakan belis tambahan atau menempuh jalan tengah yang ditawarkan leluhur dengan menegosiasikan nilainya sehingga tidak memberatkan pihak manapun.

Sikap kritis terhadap tradisi belis berdasarkan prinsip Alkitab dapat mengarahkan orang Kristen pada sikap moderat di mana prinsip-prinsip belis yang tidak bertentangan dengan Alkitab dan bersifat positif perlu dipertahankan. Ini berarti tradisi belis tidak perlu ditolak, apalagi ditiadakan oleh orang Kristen Sumba. Sebaliknya, orang Kristen Sumba dapat mempraktikkan tradisi belis dalam bentuk yang ditransformasi berdasarkan prinsip Alkitab. Hal ini dilakukan dengan meniadakan prinsip yang bertentangan dengan Alkitab dan memperbaiki praktik belis yang lahir dari distorsi terhadap prinsip-prinsip agung yang diturunkan leluhur.

Sikap moderat terhadap tradisi belis - yang melibatkan transformasi tersebut - tidak hanya mengembalikan praktik belis pada makna dan posisi seharusnya, tetapi juga mengangkatnya ke posisi yang lebih mulia karena disesuaikan dengan prinsip-prinsip yang diberikan Allah dalam Alkitab. Dengan demikian, gereja di Sumba perlu berinisiatif dan aktif mendidik jemaatnya dan membekali mereka dengan kapasitas untuk memahami prinsip-prinsip kitab suci, yang akan berfungsi sebagai pisau analisis terhadap berbagai prinsip kebudayaan Marapu yang memengaruhi mereka, termasuk prinsip-prinsip tentang pernikahan dan belis.

Kapasitas ini menjadikan jemaat sebagai orang Kristen yang dewasa dan kritis. Mereka tidak perlu meninggalkan identitas sebagai orang Sumba dan kebudayaannya - seperti belis - tetapi mampu mengambil sikap yang tepat terhadap kebudayaan. Oleh sebab itu, penelitian selanjutnya dapat 
memanfaatkan hasil penelitian ini untuk meneliti bagaimana gereja di Sumba dapat membina warganya untuk bersikap terhadap tradisi, termasuk praktik belis yang telah menjadi salah satu masalah sosial di Sumba.

\section{Daftar Isi}

Alybina, Tatiana. "Vernacular Beliefs and Official Traditional Religion: The Position and Meaning of the Mari Worldview in the Current Context." Approaching Religion 4, no. 1 (2014): 89-100.

Anggraeni, Silvia., Beding, B. Michael., Kalunga, Norlina R. Jola., Yuwono, Godril D. Perempuan Sumba dan Belis. Sumba Timur: BAPPEDA Pemerintah Kabupaten Sumba Timur dan Lembaga Pro Millenio Center, 2003.

Barclay, William. Pemahaman Alkitab Setiap Hari. Jakarta: BPK Gunung Mulia, 2015.

Boersema, Jan. Perjumpaan Injil dan Budaya dalam Kawin-Mawin. Jakarta: Yayasan Komunikasi Bina Kasih, 2015.

Carson, D.A. Kristus dan Kebudayaan: Sebuah Kajian Baru. Surabaya: Penerbit Momentum, 2018.

Denscombe, Martyn. The Good Research Guide: For Small-Scale Social Research Projects. 5th ed. New York: Open University Press, 2014.

Forth, Gregory. Rindi: An Ethnographic Study of a Traditional Domain in Eastern Sumba. Leyden: Brill, 1981.

Hamilton, Victor P. The New International Commentary on the Old Testament: The Book of Genesis Chapter 18-50. Edited by R.K. Harrison and Robert L. Hubbard Jr. Grand Rapids, Michigan: William B. Eerdmans Publishing Company, 1995.

Harari, Yuval Noah. Sapiens: A Brief History of Humankind. United Kingdom: McClelland \& Stewart, 2014.

Kamuri, Johanis Putratama. "Menimbang Posisi Penganut Marapu Di Hadapan Pemerintah Negara Republik Indonesia." Societas Dei: Jurnal Agama dan Masyarakat 7, no. 1 (2020): 73-98.

Kapita, Oe. H. Masyarakat Sumba dan Adat Istiadatnya. Jakarta: Percetakan BPK Gunung Mulia, 1976.

Kleden, Dony. "Belis dan Harga Seorang Perempuan Sumba (Perkawinan Adat Suku Wewewa, Sumba Barat Daya, NTT)." Jurnal Studi Budaya Nusantara 1, no. 1 (2017): 56-70.

Lahade, John R. Perempuan, Kuda dan Tenun: Kedudukan Perempuan dalam Keluarga di Masyarakat Wewewa, Sumba. Salatiga: Widya Sari Press, 2011. 
Laugrand, Frédéric. "The Transition to Christianity and Modernity among Indigenous Peoples." Reviews in Anthropology 41, no. 1 (2012): 1-22.

Natar, Asnath Niwa. "Penciptaan dalam Perspektif Sumba: Suatu Upaya Berteologi Ekologi Kontekstual." GEMA TEOLOGIKA: Jurnal Teologi Kontekstual dan Filsafat Keilahian 4, no. 1 (2019): 101-120.

Niebuhr, Richard. Christ and Culture. New York: Harper \& Row, Publishers, Inc., 1953.

Packer, J.I., Merrill C. Tenney, and William White, Jr. Ensiklopedi Fakta Alkitab 2. Jawa Timur: Penerbit Gandum Mas, 2009.

Patterson, Paige. "Encountering Culture in Light of The Book of Daniel." Southwestern Journal of Theology 55, no. 1 (2012): 52-62.

Putratama Kamuri, Johanis. “Transformasi Wawasan Dunia Marapu: Tantangan Pembinaan Warga Gereja di Sumba." Evangelikal: Jurnal Teologi Injili dan Pembinaan Warga Jemaat 4, no. 2 (2020): 131-143.

Putratama Kamuri, Johanis. "Yesus Dan Machiavelli: Moralitas, Religiusitas, dan Kompetensi Politisi di Ruang Publik." Societas Dei: Jurnal Agama dan Masyarakat 6, no. 2 (2020): 168-191.

Schilbrack, Kevin. “What Isn't Religion?" The Journal of Religion 93, no. 3 (2013): 291-318. https://www.jstor.org/stable/10.1086/670276.

Sekretariat Sinode GKS. Garis-Garis Besar Kebijakan Umum Gereja Kristen Sumba (GBKU-GKS) Periode 2014-2018. Waingapu: Badan Pelaksana Majelis Sinode GKS, 2014.

Waltke, Bruce K., and Cathi J. Fredricks. Genesis: A Commentary. Grand Rapids, Michigan: Zondervan, 2001.

Walukati, Yonathan Lu. "Tradisi Kawin Mawin Suku Sumba: Belis atau Beli?" Kompasiana. Terakhri dimodifikasi 2018. https:// www.kompasiana.com/yonshunga/5bcfcf5aaeebe143155b87d5/ tradisi-kawin-mawin-suku-sumba-belis-atau-beli? page=2.

Wara, Yanuarius L., Widianto, Tri., Purwiyastuti, Wahyu. Tradisi Belis dalam Upacara Perkawinan dan Perubahan Sosial, Budaya, Ekonomi Masyarakat Sumba Barat Daya. Semarang: Widya Sari Press, 2015.

Wellem, F.D. Injil dan Marapu: Suatu Studi Historis Teologis tentang Perjumpaan Injil dengan Masyarakat Sumba pada Periode 1876-1990. Jakarta: BPK Gunung Mulia, 2004.

West, Jim. "The Distinctivenes of 'Two Kingdoms' Theology." Unio Cum Christo 4, no. 1 (2018): 133-151.

Wright, N.T. God in Public. London: Society for Promoting Christian Knowledge, 2016. 